\title{
Reproductive Behaviour, Hematological Profile and Monogenean Microfauna of the Nest-Breeding, Nile Green Tilapia (Tilapia zilli) Gervais, 1848
}

\author{
El-Naggar; AM ${ }^{1}$; El-Tantawy, SA ${ }^{1}$; Mashaly, MI ${ }^{1}$; Kanni, A $^{2}$ \\ ${ }^{1}$ Zoology Department, Faculty of Science, Mansoura University, Egypt \\ ${ }^{2}$ Zoology Department, Faculty of Education, Sabha University, Libya
}

\begin{abstract}
The aims of the present study were to throw lighton somebehaviouralaspectsof the nest-breeding Nile green tilapia, Tilapia zilli in one of its natural environments, namely Mansouria Canal, Nile Delta, Egypt, to clarify the relationship between these aspects and some hematological and biochemical parameters, and toestimate the infection variables of ectoparasiticmonogeneans on this cichlid host. During the spawning time, males and females of the green tilapia were observed to colour up, cooperatein diggingthe spawning pits, defend their eggs, and pay intensive care to theirfingerlings.Hematological testsshowed significantly higher levels of the thrombocytes (PLT), serum catalase (CAT) and malondialdenhde(MDA)in the breeding than nonbreeding forms. However, the erythrocytes (RBCs),leucocytes (WBCs) and hematocrit (HCT) attained lower, but non-significant, count in the blood of the nest mates. Similarly, other hematological and biochemical indices showed no significant variation between the two forms of the green tilapia. There were no serum bactericidal activities against Vibrio cholera, Pseudomonas and Salmonella spp.Factors contributing to the spawninginduced stress and possible influences of the hormonal and physiological manifestations on themonogenean infestation level on the breeding forms of tilapia are discussed, with reference to the behavioural and physiological aspects of the conspecific, non-nesting forms of tilapia.
\end{abstract}

Keywords: Mansouria Canal, Tilapia zilli, Reproductive Behaviour, Hematological Profile, Monogenean Microfauna.

\section{Introduction}

Recent environmental impactassessment projectsindicate that the hematological and biochemical parameters are an indicative tool for assayingmodifications in the normal physiology, and can provide invaluable data about the overall health of fish $[1,2,3]$. The stress is defined as a condition in which homeostasis (i.e. the affinity of an organism to adjust its internal environment) is alteredin response to the arrangementsof intrinsic or extrinsic circumstances [4]. According to [5, 3], fish undergo stress in captivity, a characteristic feature of the nest mates which devote their activities to the spawning ground. Hematological parameters of fish can reflect some aspects of stress $[6,7,5]$. [8] contributed the validity of the hematological variables, serum enzymes and hormones as bioindicators of the fitness of fish to the fact that fish are merely impregnated in the aquatic environment and their blood image (profile) can express an array of mechanisms regulating the body functions of these organisms. This procedure can provide an early sign prior to thepropagation of disease.

Physiological and immunological aspectsof fish are strongly affected by abiotic (non-living) and biotic (living) elements of the surrounding environment. Teleost fish exhibit similar immune responses to mammals, including non-specific (innate or natural) and specific (acquired or adaptive) mechanisms [9]. The reproduction of fish, and particularly the spawning course,exhibitscrucialinfluences on different biological mechanismsof the mating partners [10]. Imagingthe blood includes defining the total red blood cell count (RBCs), total white blood cell count (WBCs), hematocrit (HCT), hemoglobin concentration (HGB), in addition tothe erythrocyte indices $(\mathrm{MCH}, \mathrm{MCV}, \mathrm{MCHC})$ [11]. Estimating the biochemical profile comprises a range of chemical compounds and enzymes in the blood that likely reflect theoverallcondition andgeneral health status of the organism. Modifications in the hematological indicesrely upon fish age,sex and sexual maturity cycle $[12,13$, $14,7,15]$. A complete profile of the hormonal and physiological manifestationsof the nest-breeding tilapiawould enrich our understanding of the interaction between the fish host andits environment, including physical, chemical and biological factors. [16] reviewedthe role of parasites and immunological resistance in host sexual selection based on physiological systems and tradeoff (i.e. be deprived of one aspect as an exchange for gaining another), with reference to the breeding, sexual coding and immune task. [17] studiedthe relationship betweensex hormones, attractive colourationand potency for immunologic response.[18] demonstrated the significance of sex hormones in regulating the allocation of resources between immune mechanisms and reproductive arrangements.[19] studied the relationship between sperm quality, ornamentation, 
sex hormones and immunity.[16] investigated the interplay between stress, testosterone and allocation to different components of the immune system, and showed that sexual displays specifying parasite resistance in male vertebrate hosts are activated by testosterone, a seemingly immunosuppressive hormone.[20] suggested that different parasite life-strategies affect diverse features of the host physiological manifestations and trigger various immunity pathways. They found that fish with a poorer condition rank were infested more by monogenean parasites, which are the most abundant parasite group. Moreover, higher cestode burden seemed to stimulate phagocytosis [20]. Tilapia zilli is native to Africa and has been introduced to many geographical areas around the globe. It is an omnivore cichlid,feeding on a variety of food items of plant and animal origin, and is regarded in aquaculture systems as a profitable source of the animal protein (e.g. [21]).This cichlid fish contributes to about $71 \%$ of the world total tilapia production [11]. This cichlid is naturally distributed throughout the lake systems of the Northern and Western Africa [22, 23]. Of particular interest is the study of hematological and biochemical parameters of the nest-breeding tilapia that spawns in shallow, inshore water over a period of approximately five months (from early April to late August). Owing to their limited range of movement, nest matesin territories may become more susceptible to physicochemical and biological parameters which may alter the blood components and chemistry profile. To the best of our knowledge, no previous reports were made of the hematological profile of $T$. zilli in the freshwater streams of Egypt. The present investigation aimed atevaluating the impacts of the breeding environment on some hematological and biochemical parameters,and exploring the possible impacts of the reproductive behaviouron monogeneanmicrofauna of the breeding tilapia.

\section{Materials And Methods}

\subsection{Study Area:}

Mansouria canal (Figure 1) is one of the primary freshwater resourcesin the Nile Delta, Egypt. The canal is regarded as the life artery for millions of people and provides thousands of acres of cultivatedareaswith a predominant water supply in such amazing and highly populated geographical area of Egypt. In addition, Mansouria Canal is a nursing ground for a variety of fish kinds that meet the growing needs of the community for the animal protein. The canal is affected by many anthropogenic activities and bad practices (Figure 1B). The study area is locatedin the vicinity ofSalaka Village, MansouraCity (Figure 1A).

\subsection{Field observations and Fishing:}

Specimens of Tilapia zilli were caught monthly during the breeding season that extends from early April to late August in 2016. Immediately after capture with rod and line, the fish were kept alive in appropriate container provided with an air pump. Then, the fish were transported to the laboratory as soon as possible to minimize the stress of the captive fish. At the laboratory, the harvest was assorted into males and females. Observations were made of the nest selection, nest building, spawning pit digging, egg deposition and rearing, and parental care in $T$. zilli was inspected with the aid of video-camera systems. Close inspection of the reproductive behaviour was made only during daytime.

\subsection{Hematological studies:}

Hematological parameterssuch as hemoglobin content and the number of red blood cells (RBCs), white blood cells (WBCs) and blood platelets (PLT) were determined using standard hematological techniques. Using a hypodermic needle, a 3-ml syringe immersed in EDTA, few millimeters of blood were withdrawn from the caudal vein of freshly caught and physically fit tilapia.For proper collection of the blood, the needle was tilted to acquire an angle of $45^{\circ}$ from the peduncle. Then, the sterilized needle was inserted carefully into the skin and between the scales. Immediately, the needle was pushed skillfully into the underlying tissues and straight down toward the core area of the peduncle, to reach the blood stream in the tail region. When the blood began to flow inside the needle, a pressure was maintained on the plunger, which was released once the target amount of blood was obtained.

Two sampling protocols were designed. The first blood sample was transferred to EDTA tube containing Sodium Thiosulphate as an anticoagulant factor. Each blood sample was allowed to coagulate for about 20 minutes.Immediately after settlement of the blood components, the blood was prepared for subsequent treatment. This blood sample was transferred assoon as possible to be imaged or analyzed by Hematology Analyzer (Mindray BC-3200) at the Nile Research Center. The second blood sample was collected in anticoagulant-free tubes and then centrifuged at $3000 \mathrm{rpm}$ for $15 \mathrm{~min}$.According to [24], the red blood cells were separated from plasma and the haemolysate (i.e. pale straw supernatant as a result of the lysis of erythrocytes) was produced. This procedure was repeated two or three times to obtain clear and transparent haemolysate. Following centrifugation, the supernatantwas isolated safely and kept in the cold freeze until analyzed later for serum enzymes, hormones and bactericidal activity. 
The blood image comprised the red blood cells (RBCs), white blood cells (WBCs), hemoglobin content (HGB), platelets (PLT), hematocrit ratio (HCT), mean corpuscular volume (MCV), mean platelets volume (MPV), lymphocytes (LYM), red cell distribution width (RDWc) and platelet distribution width (PDWc). Estrogen and Testosterone to measure sex hormones. Levels of these hormones were determined by Vidas mini 30, an automated immunoassay tests utilizing ELFA (Enzyme Linked Fluorescent Assay) technology. The concentrations of Estradiol (E2) and Testosterone (T) were determined by radioimmunoassay using 1251 RIA kits (ICN pharmaceuticals) [25].The serum bactericidal activity was indicated by Vibrio cholera, Salmonella and Pseudomonas spp. The activity of the three species of bacteria was tested by the activity of serum antibody using Laminar Flow System.

A freshly dissected segment $(0.32 \mathrm{gm})$ of the first gill arch (right gill set)was weighed by VIBR HT 220/0.0001 electronic balance andhomogenized in distilled water using a Heidolph Homogenizer (5000-26000 rpm speed). Then,the gill tissue homogenate was digested with $1 \mathrm{ml}$ of $0.1 \mathrm{~N} \mathrm{NaOHfor}$ an hour at $98^{\circ} \mathrm{C}$. The digestate was then centrifuged in Sigma 1-14 Centrifuge and the supernatant was introduced into Implen P330 Nanophotometer to determine the levels of the Nitric oxide (NO), Catalase (CAT), Glutathione I (GSH), Glutathione II (GST) and Malondialclenhyde (MDA). Catalase activity,measured in U units, was measured at $540 \mathrm{~nm}$. The measuring unit of catalase is defined as the quantity of catalase required to decompose one $\mu$ mol of hydrogen peroxide $\left(\mathrm{H}_{2} \mathrm{O}_{2}\right)$ per minute at $25^{\circ} \mathrm{C}$ and $\mathrm{pH}=7$ [26].

\subsection{Statistical analysis:}

All data were recorded as (Mean $\pm \mathrm{SD}$ ). Two parametric tests were chosen on the SPSS package (version 20), namely One-Way ANOVA and Student's $t$-Test. The parametric One-Way ANOVA Test was utilized to explore variations of the hematological parameters between the four forms of tilapia. The Student's $t$ Test was employed to explore variations of the blood parameter (count of corpuscles, hemoglobin, hematocrit, hormones and antioxidants) between males and females of the two forms, between males of the breeding and their corresponding genders of the non-breeding forms, as well as between females of the breeding and their corresponding genders of the non-breeding forms. Probability values were selected as follows:P $\leq 0.05$, significant; $\mathrm{P} \leq 0.01$, highly significant and $\mathrm{P} \leq 0.001$, very highly significant.However, $\mathrm{P}$-values $>0.05$ were considered as non-significant.

\section{Results}

\subsection{Reproductive behaviour in Tilapia zilli:}

\subsubsection{Nest localization, construction and guarding:}

Earlier in April, males and females of the nest-breeding tilapia, Tilapia zilli intending to spawn arrived to the inshore, shallow water zone atMansouria Canal. The mating partners were observed to select a muddy spawning ground (Figure 2A), exposed to the direct sunlight. In some occasions, spawning couples were observed,on the video-camera system, to select their nests on relatively flattened surface of stones (Figure2B) or other solid objects settlingat the bottom. Furthermore, some large-sized mates were observed to occupy vertical grooves in the shoreline and dig a few pits on the base of these grooves (Figure 3A). Intensive field observations revealed that both males and females of the breeding tilapia began to colour up on the commencement of the spawning season(Figure 3B). Nesting forms appeared slender and were confined to the ground throughout the spawning time. Both sexes attained shiny, attractive yellowish coloration, with a prevailing red throat (red belly).

Morphometric measurements revealed that males were usually larger and likely older than females. Spawning couples constructed a variable number of bowl-shaped excavations in the muddy substratum. Deposited eggs were hardly seen on the grayish or yellowish surface of the stones or other solid materials. On the muddy substrate, more than 10 couples were seldom observed to construct closely-spaced spawning nests on wide arenas. These spawning grounds showed reciprocal stimulation of adjacent nest mates and aggressiveness of the mating partners towards intruders.

Frequently, large-sized males and females were recognized in the vicinity of the spawning grounds, however they exhibited less ornamentation and were not involved in the spawning course. Non-nesting forms were fat, whitish-grey in colourand displayed random and vigorous movements nearby the nesting mates that fight and frightened the intruders either by aggressive, mouth-to-mouth, biting or rapid physical displacements.Close inspection with the aid of the video-camera system revealed that the spawning nest was guarded by both male and female fish. On the one hand, nesting males were more movable than females, and defended the periphery of the spawning nest. On the other hand, nesting females were relatively quiescent, occupied the median area of the spawning nest, and defended their eggs/offspring against intruders and contaminants driven by the water current. 


\subsubsection{Egg rearing and care of offspring:}

The egg clusters (Figure4A) were usually observed on relatively flattened, solid objects in the spawning area. The emerging fries were never seen in the vicinity of the spawning nest during the first few days after egg hatching. A few days later, many mating partners as well as their developing fries left the spawning ground and swam freely in water close to the shoreline. With the aid of video-camera system, the fries were seen moving as a unified shoal according to the instructions of the parent female that was located in the center of the shoal (Figure 4B). On the other hand, the parent male was observed to occupy the marginal area of the territorial swimming shoal.

\subsubsection{Biological associations (intraspecific and interspecific):}

Many biological associations (interactions) and behavioural patterns were documented throughout the spawning period of the nest-breeding tilapia atMansouria Canal. These biological associations include competition, predation, egg cannibalism and altruism. The behavioural aspects comprised nest building, nest guarding, parental care, social life (cooperative defense and colonial breeding), communication and agnostic behaviour. Simple styles of learned behaviour were recorded during the period of water decline by the end of the breeding season.

Egg cannibalism was common either by pirates of the non-nesting tilapia, swimming actively close to the margin of the spawning ground, or other intruders such as the DayglowfuluHaplochromisbloyeti, the two spotted jewelfish Hemichromisguttatus, the white tilapia Oreochromisniloticusniloticus, the mango tilapia Sarotherodongalilaeusgalilaeus, the crayfish Procambarus clarkia or the freshwater crab Liocarcinusvernalis. The latter was observed to prefer more sheltered places beneath stones and solidobjects. The crayfish was highly aggressive and frequently attacked the spawning nests, preyed upon nesting couples and occupied their vacant niches. The crayfish was observed to make menacing gestures with the aid of their massive claws. They were observed to burrow deep, inshore holes into the mud and frequently threatened the life of the nesting tilapia. These omnivorous and scavengers were observed to frighten the spawning couples at regular intervals. The aggressivebehaviour was practiced by the nest mates, however females were more aggressive than males. The nest mates showed strong offense displays to secure their territory against the crayfish, crab, conspecifics and other sympatric species.

From September 2016 onwards, Mansouria Canal showed an irregular filling and draining cycles (Figure 1C). At this time, nest mates were found to experience simple learning tactics; each mating partner prepared two alternative nesting grounds and allocated the building and guarding efforts between the two grounds. However, the two nesting ground were constructed at the same depth, close the shoreline.

\subsection{Monthly occurrence of ectoparasiticmonogeneans on the gills of Tilapia zilli during the spawning period:}

Out of 155 examined fish, a total of 337 monogenean worms were isolated and identified. The breeding forms of the green tilapia were infested with 270 worms, whereas the non-breeding forms were parasitized by 67 worms. The monogeneanCichlidogyusarthracanthus recorded the highest number (163 worms), followed byC. aegypticus (53 worms) and C. tilapiae (47 worms). However, the monogeneanC. hallitypicus attained the lowest number (16 worms). A total of 178 monogenean worms were collected from the gills of 51 breeding males, whereas a total of 92 monogenean worms were collected from the gills of 25 the breeding females of the green tilapia. On the other hands, a total of 50 monogenean worms were found on the gills of 52 non-breeding males, whereas a total of 17 monogenean worms were encountered on the gills of 27 non-breeding males of tilapia.

As shown in Table 1 and Figures 5 and 6, the monthly prevalence values of all the studied monogenean speciesare higher in the breeding than non-breeding forms of Tilapia zilli. The monogeneanC. arthracanthus is the core (most dominant) species in the breeding and non-breeding forms, with mean prevalence values of 64.19 and $21.11 \%$ in the two forms respectively. The cohabitant monogeneanC. aegypticus comes second, with mean prevalence values of 26.67 and $4.22 \%$ in the breeding and non-breeding forms respectively. The monogeneanC. hallitypicus recorded the lowest mean prevalence values in the two forms of tilapia (Table 1).

The monthly mean intensities of the monogeneans $C$. arthracanthus, $C$. aegypticus, $C$. hallitypicus and C. tilapiae on the gills of the breeding and non-breeding forms of T.zilli are recorded in Table 2 and graphically represented in Figures 7 and 8.Regarding the breeding forms of tilapia, the highest mean intensity value was recorded for C. arthracanthus(3.21), while the lowest level was found for C. tilapiae and C.hallitypicus (1.50). On the other hand, on the non-breeding forms of tilapia, the maximum mean intensity value was recorded for $C$. arthracanthus(1.07), while the lowest value was found for $C$. hallitypicus $(0.50)$.

It can be noticed from Tables1, 2 and 3 that all the studied monogeneans were completely absent from the gills of the non-breeding forms of tilapia during May and June. Except for the most dominant $C$. 
arthracanthus, all monogeneans were not encountered on the gills of the non-breeding tilapia during August. A similar disappearance in August was recorded for the monogeneansC. tilapiae and C. hallitypicus on the gills of the breeding tilapia. The rare monogeneanC. hallitypicus was also absent from the gills of the breeding and nonbreeding tilapia during July.

From Table 3 and Figures9 and 10,the abundance values of the monogenean parasites on the breeding were higher than those on non-breeding forms of $T$. zilli. The highest mean abundance value was detected for $C$. arthracanthus(2.28) in the breeding forms, however the lowest mean abundance value was obtained for $C$. aegypticus and $C$. hallitypicus (0.06). Also, a markedly low mean abundance level (0.08) was found for $C$. tilapiae on the breeding tilapia (Table 3 ).

\subsection{Hematological and Biochemical parameters of Tilapia zilli during the spawning period: 3.3.1. Hematological parameters}

Tables 4A and 4B show the monthly variations of the hematological parameters in the blood of T.zilli caught from Mansouria Canal during the period from April to August 2016. The hematological parameterscomprisedhemoglobin (HGB), red blood cells (RBCs), hematocrit (HCT), mean corpuscular volume (MCV), mean corpuscular hemoglobin $(\mathrm{MCH})$, white blood cells (WBCs), Lymphocytes (LYM), platelets (PLT), red cell distribution width (RDWc), mean platelet volume (MPV), and Platelet distribution width (PDWc). Except for a considerable difference in the count of thrombocytes, there are slight variations in the levels of hematological parameters between the two forms of tilapia (Tables4A and 4B).

From Table 4A, the hemoglobin level varied between 6.90 and $13.1 \times 10^{3} / \mu 1$. The mean hemoglobin value in the breeding forms was $11.2( \pm 1.10) \times 10^{3} / \mu 1$ and in non-breeding forms $10.84( \pm 1.90) \times 10^{3} / \mu 1$.The mean RBCs count in the breeding forms was $1.71( \pm 0.16) \times 10^{6} / \mu 1$ and in the non-breeding forms $1.81( \pm 0.21)$ $\times 10^{6} / \mu 1$. As shown in Table 4A,the mean values of HCT in the breeding forms of T. zilliwas $24.98( \pm 3.11) \%$ and in the non-breeding $25.13( \pm 3.40) \%$. The mean value of MCV in the breeding forms was $137.70( \pm 9.38) \mathrm{fl}$ and in the non-breeding forms $133.24( \pm 12.22)$ fl (Table 4A). Records documented in Table 4Ashow that the values of $\mathrm{MCH}$ in the breeding and non-breeding forms of $T$. zilli were $62.3( \pm 3.59) \mathrm{pg}$ and $58.50( \pm 8.91)$ pgrespectively.

From Table 4B, the mean WBCs value in the breeding forms was $91.90( \pm 11.38) \times 10^{3} / \mu 1$ and in the non-breeding forms $103.10( \pm 11.02) \times 10^{3} / \mu$. The mean lymphocytes count in the breeding forms was 70.64 $( \pm 11.18) \times 10^{3} / \mu \mathrm{l}$ and in the non-breeding forms $68.56( \pm 16.25) \times 10^{3} / \mu 1$. As shown in Table 4B, the mean PLT value in the breeding and non-breeding forms are $140.70( \pm 19.92) \times 10^{3} / \mu 1$ and $115.70( \pm 31.95) \times 10^{3} / \mu 1$ respectively. The mean RDWc value in the non-breeding forms was $17.00( \pm 3.63) \%$ and in the breeding forms $13.50( \pm 2.37) \%$. Table 4B shows that the mean MPV value in the breeding forms is $8.92( \pm 0.83) \mathrm{fl}$ and in nonbreeding forms $8.43( \pm 1.06) \mathrm{fl}$. Data documented in Table 4B show that the mean values of PDWc in the breeding and non-breeding forms of the green tilapia are $36.52( \pm 8.81)$ and $35.57( \pm 10.08) \%$ respectively.

\subsection{Biochemical parameters \\ 3.4.1. Hormones}

Tables 5A and 5Brepresent the output of the analysis of sex hormones Estrogen and Testosterone respectively.From Table 5A, the level of estrogen hormone attained considerablyhigher values in the breeding females than non-breeding females. The mean values of the hormone in the breeding and non-breeding females were $500.66( \pm 249.07) \mathrm{pg} / \mathrm{ml}$ and $396.82( \pm 202.01) \mathrm{pg} / \mathrm{ml}$ respectively. Concerning the breeding forms, the highest level was estimated during July, while the lowest level was recorded during April at the commencement of the spawning period (Table 5A). Regarding the non-breeding forms, the highest level was estimated during April, while the lowest level was recorded during August at the termination of the spawning period (Table 5A). It is obvious form Table $5 \mathrm{~B}$ that the level of testosterone hormone attained considerably higher values in the breeding females than non-breeding females. The mean values of the hormone in the breeding and non-breeding females were $4.82( \pm 3.34) \mathrm{ng} / \mathrm{mland} 3.59( \pm 3.07) \mathrm{ng} / \mathrm{ml}$ respectively. Concerning the breeding forms, the highest level was estimated during April, while the lowest level was recorded during August (Table 5B). Regarding the non-breeding forms, the highest level was estimated during August, while the lowest level was recorded during May (Table 5B).

\subsubsection{Antioxidant activity}

Obtained values of the nitric oxide (NO), catalase (CAT), malondialdenhde (MDA) andglutathione (GST, GSH) are recorded in Table 6. The breeding forms attained higher levels of NO and GSH than nonbreeding forms. In contrast, the non-breeding forms showed higher levels of CAT, MDA and GST than breeding forms of the green tilapia

Student's $\mathrm{t}-$ Test on SPSS program (version 20) revealed significant differences in the number of PLT $(\mathrm{t}=2.100$, $\mathrm{p} \leq 0.05)$, MDA $(\mathrm{t}=-2.102, \mathrm{p} \leq 0.05)$ and CAT $(\mathrm{t}=-2.425, \mathrm{p} \leq 0.05)$ between the breeding and non-breeding 
forms of T. zilli. However, the two forms of the green tilapia showed no significant variations in the other hematological and biochemical parameters. ( $p>0.05$ in all cases).

\subsubsection{Bactericidal activity}

The bactericidal activity forVibrio cholera, Pseudomonas and Salmonellawas analyzed in the blood serum of monthly collected samples. There was no activity against any different bacterial species (Vibrio cholera, Pseudomonas, and Salmonella) in the blood serum (Figures 11A, 11B and 11C).

\section{Discussion}

The blood parameters are regarded as a successful bioindicator or biomarker of the environmental stress as they reflect the physiological and immunological conditions of the aquatic organisms. [27]suggested that data obtained from the hematological analysis of fish might provide valuable information about the characteristic features of the waterbody in stressed ecosystems. [28, 29] highlighted the effects of fish gender on the hematological parameters. [30] highlighted the importance of hematological approaches as an understanding tool of the relationship between elements of the blood and the habitat, and adaptive responses of the living organism to the environment. The authors recommended the establishment of normal blood profiles and standard hematological criteria for different fish species. The present study providesa baseline data for the blood profile of the nest-breeding tilapia, Tilapia zilli during the breeding season and associated physiological and behavioral patterns. These information may help facilitate the maintenance and improvement of the fish populations atMansouria Canal. [31] stressed that monitoring fish hematology requires reference data, close to the normal levels of different blood parameters as reliable descriptors of the fit body of fish under ordinary circumstances.[5] employed the blood parameters as a mirror reflecting the health condition of an array of fish to estimate the physiological alterations as a result of exposure to pollution and hypoxic conditions, in addition to other waterborne stressors. [8] reported that fish as well as other aquatic organisms are directly influenced by the fluctuations of the aquatic environment and stressed that the blood profile readily reflects the internal environment of the body of fish. This can represent an early sign prior to the development of disease.

Antioxidant enzymes are important for ideal fish development. Moreover,they support the body immune system. The antioxidant arrangements in the living organism may be categorized into two forms: one is signified by enzymes, e.g. superoxide dismutase, catalase and peroxidases thateradicate reactive oxygen species (ROS). Other antioxidantspick up free radicals. According to [32], the manner of action of antioxidants is classified as follows: removing oxygen or decreasing local $\mathrm{O}_{2}$ concentrations, removing catalytic metal ions, removing reactive oxygen species, scavenging initiating radicals, breaking the chain of an initiated sequence, quenching or scavenging singlet oxygen.[33] suggested that ROS- and free radicals induced antioxidant peroxidation may be greatlyharmful, leading to damage in cellular membranes.

According to [30], fish blood constitutes up to $7 \%$ of its body weight. Fish blood is one of the most vital components and is concerned with gas exchange between the body of fish and oxygen-holding water in the aquatic environment. [34] highlighted the importance of the blood parameters as an early alarming sign of the stress response in fish to abiotic and biotic factors. As a measure of the quality and quantity of RBCs, WBCs and PLT, the complete blood count (CBC) is regarded as an important and informative diagnostic tool in ecotoxicological reports and fish health assessment assays [35, 36]. The hematocrit (HCT)designates how many red blood cells are existing. Lower HCT levels might indicate the onset of anemia, while higher HCT mightpoint to dehydration. The hemoglobin ( $\mathrm{Hgb}$ ) can help determine how well the red blood cells are carrying oxygen to differenttissues. Higher numbers of the white blood cells (WBC) may be a response to an infection or inflammation [36]. In contrast, lower numbers of the white blood cells may indicate a serious infection or bone marrow dysfunction. The platelets count (PLT) measures the quantity of platelets, which are involved in the blood clotting process [37].

The hematological analysis indicated significantly higher levels of the blood platelets in the breeding than non-breeding forms of the green tilapia. The mean values of PLT were $140.70( \pm 19.92) \times 10^{3} / \mu 1$ and $115.70( \pm 31.95) \times 10^{3} / \mu 1$ in the breeding and non-breeding forms, respectively. However, the red blood cells (RBCs) and white blood cells (WBCs) recorded lower, but non-significant, count in the blood of the breeding than non-breeding forms of T.zilli. The mean values of RBCs in the blood of the breeding and non-breeding forms were $1.71( \pm 0.16) \times 10^{6} / \mu 1$ and $1.81( \pm 0.21) \times 10^{6} / \mu 1$ respectively. The mean values of WBCs in the blood of the breeding and non-breeding forms were $91.90( \pm 11.38) \times 10^{3} / \mu 1$ and $103.10( \pm 11.02) \times 10^{3} / \mu 1$ respectively.

The white blood cells (WBCs) act as the primary force of the immune system in aquatic animals. [38] suggested that this blood cell type has a significant role in the immune responses and defense tactics. Optimization of the white blood cells count seems likely to indicate integration of the cellular immune responses and increased ability to interplay with pathogens and multisource stressors. The relatively lower count of the white blood cells on the breeding forms of $T$. zilli may indicate a stress condition in the breeding 
males and females. To verify a successful reproductive output, breeding forms of tilapia must direct their energetics to the production of high quality gametes, selection of the fertile partner, nest-building and guarding, optimal oviposition and intensive care of the fertilized eggs. These activities indeed overconsume the stored energy and assimilatory elements across the organ systems of the body. [3] studied the hematology of $O$. niloticus after acclimation to captivity and found that the stress condition in the fish created changes in the white blood cells and differential counts neutrophils, monocytes and lymphocytes. Owing to data obtained in the present work, neither the count of the red blood cells nor the level of hemoglobin showed marked variation between the breeding and non-breeding forms of $T$. zilli.

In the present study, hemoglobin levels varied insignificantly between the blood profile of the breeding and non-breeding forms of the green tilapia. The mean values obtained for HGB were $11.2( \pm 1.10) \times 10^{3} / \mu 1$ and $10.8( \pm 1.90) \times 10^{3} / \mu 1$ in the breeding and non-breeding forms, respectively. Hemoglobin is a highly important biological molecule. It is a respiratory pigment capable of transporting oxygen molecules to the blood. The normal hemoglobin level in T.zilli has not been changed significantly between the two fish categories, indicating an adaptation of the breeding forms.

According to $[39,40,41]$ the blood platelets (thrombocytes) attain the ability to phagocytose pathogens and play a role in the defense mechanisms. [42] suggested that the thrombocytes act as a link between the innate and adaptive immune systems of the fish. [11] showed that the blood platelets express surface and intracellular molecules, which are involved in immune function. Many studies indicated that fish thrombocytes are blood phagocytes, which form an important tool of the protective barriers in fish (e.g. [43, 44]) Significantly higher levels (counts) of the blood thrombocytes of the breeding forms of the green tilapia seem likely to represent an immune response and a healing process following frequent injuries induced by invaders of the nesting arenas such as antagonistic, non-breeding males of the cichlid fish and the freshwater carb, Liocarcinusvernalis and the crayfish,Procambarusclarkii.

The secondary blood indices, MCHC, MCH, MCV, MPV, RDWc, WDWc and PDWc showed nonsignificant difference between the mating partners and non-mating dwellers of the green tilapia. [45] reported that the mean cell hemoglobin level is an index used to assess the number of red cell swelling (low MCHC) or shrinkage (high MCHC) found in the blood sample.

Fish immune system possesses mechanisms responsible for defense against bacteria, through pathways mediated by macromolecules originating in the outside of the plasma membrane (humoral immunity), for example antibodies andantimicrobial proteins, stemming from a number of differentcauses or influences which aim at preventing bacterial colonization. On the other hand, tools of the innate mechanisms (cell-mediated immunity) comprise the production of antibacterial compounds, phagocytosis and inflammation [46, 47], macrophages, neutrophils and phagocytes showgreatamounts of lysosomal enzymes and reactive oxygen species todevastateattacking bacteria. In the present study, no bactericidal activity was recognized in the blood of the green tilapia, indicating an effective immune response against invading pathogens by destroying colony forming units and stimulating the reduction in its numbers in the plates. This immunoassay proved the raise in the level of serum protective proteins which occurs after a natural infection.

Table (1).Monthly Prevalence Values Of The Gill Monogeneans Of The Breeding And Non-Breeding Forms Of Tilapia Zilli During The Period From April To August (2016).

\begin{tabular}{|c|c|c|c|c|c|c|c|c|}
\hline \multirow{2}{*}{$\begin{array}{c}\text { Month } \\
\text { (2016) }\end{array}$} & \multicolumn{4}{|c|}{ Breeding forms } & \multicolumn{4}{c|}{ Non-breeding forms } \\
\cline { 2 - 9 } & $\begin{array}{c}\text { C. } \\
\text { arthracanthu } \\
s\end{array}$ & C. aegypticus & $\begin{array}{c}\text { C. } \\
\text { tilapiae } \\
\text { Aallitypic } \\
\text { us }\end{array}$ & $\begin{array}{c}\text { C. } \\
\text { arthracanthu } \\
s\end{array}$ & $\begin{array}{c}\text { C. } \\
\text { aegypticus }\end{array}$ & $\begin{array}{c}\text { C. } \\
\text { tilapiae } \\
\text { hallitypicus }\end{array}$ \\
\hline April & 83.33 & 45.83 & 33.33 & 12.5 & 38.89 & 11.11 & 11.11 & 11.11 \\
\hline May & 50.00 & 16.67 & 16.67 & 16.67 & absent & absent & absent & absent \\
\hline June & 46.15 & 23.08 & 23.08 & 15.38 & absent & absent & absent & absent \\
\hline July & 56.25 & 12.5 & 0.23 & absent & 36.67 & 10 & 10.00 & absent \\
\hline August & 88.24 & 35.29 & absent & absent & 30.00 & absent & absent & absent \\
\hline Mean & 64.19 & 26.67 & 14.66 & 8.91 & 21.11 & 4.22 & 4.22 & 2.22 \\
\pm SD & \pm 19.57 & \pm 13.74 & \pm 14.55 & \pm 8.27 & \pm 19.55 & \pm 5.79 & \pm 5.79 & \pm 4.97 \\
\hline
\end{tabular}


Table (2).Monthly Mean Intensity Values Of The Gill Monogeneans Of The Breeding And Non-Breeding Forms Of Tilapia Zilli During The Period From April To August (2016).

\begin{tabular}{|c|c|c|c|c|c|c|c|c|}
\hline \multirow{2}{*}{$\begin{array}{l}\text { Month } \\
(2016)\end{array}$} & \multicolumn{4}{|c|}{ Breeding forms } & \multicolumn{4}{|c|}{ Non-breeding forms } \\
\hline & $\begin{array}{c}C . \\
\text { arthracan } \\
\text { thus }\end{array}$ & $\begin{array}{c}C . \\
\text { aegypticus }\end{array}$ & $\begin{array}{c}C . \\
\text { tilapiae }\end{array}$ & $\begin{array}{c}C . \\
\text { hallitypicus }\end{array}$ & $\begin{array}{c}C . \\
\text { arthracan } \\
\text { thus }\end{array}$ & C. aegypticus & $\begin{array}{c}C . \\
\text { tilapiae }\end{array}$ & $\begin{array}{c}C . \\
\text { hallitypicus }\end{array}$ \\
\hline May & 4.33 & 4.00 & 2.00 & 5.00 & absent & absent & absent & absent \\
\hline June & 2.00 & 1.67 & 1.00 & 1.50 & absent & absent & absent & absent \\
\hline July & 2.22 & 2.00 & 1.60 & absent & 2.45 & 1.33 & 2.33 & absent \\
\hline
\end{tabular}

Table (3).Monthly Abundance Values Of The Gill Monogeneans Of The Breeding And Non-Breeding Forms Of Tilapia Zilli During The Period From April To August (2016).

\begin{tabular}{|c|c|c|c|c|c|c|c|c|}
\hline \multirow{2}{*}{$\begin{array}{l}\text { Month } \\
(2016)\end{array}$} & \multicolumn{4}{|c|}{ Breeding forms } & \multicolumn{4}{|c|}{ Non-breeding forms } \\
\hline & $\begin{array}{c}C . \\
\text { arthracant } \\
\text { hus }\end{array}$ & $\begin{array}{c}C . \\
\text { aegypticus }\end{array}$ & $\begin{array}{c}C . \\
\text { tilapiae }\end{array}$ & $\begin{array}{c}C . \\
\text { hallitypic } \\
\text { us }\end{array}$ & $\begin{array}{c}C . \\
\text { arthracanth } \\
\text { us }\end{array}$ & $\begin{array}{c}C . \\
\text { aegypticus }\end{array}$ & $\begin{array}{c}C . \\
\text { tilapiae }\end{array}$ & $\begin{array}{c}C . \\
\text { hallitypicus }\end{array}$ \\
\hline April & 3.70 & 1.04 & 0.96 & 0.13 & 0.61 & 0.17 & 0.17 & 0.28 \\
\hline May & 2.17 & 0.67 & 0.33 & 0.83 & absent & absent & absent & absent \\
\hline June & 0.92 & 0.38 & 0.23 & 0.23 & absent & absent & absent & absent \\
\hline $\begin{array}{l}\text { Mean } \\
\pm \text { SD }\end{array}$ & $\begin{array}{c}2.28 \\
\pm 1.23\end{array}$ & $\begin{array}{c}0.56 \\
0.31 \pm\end{array}$ & $\begin{array}{c}0.40 \\
0.36 \pm\end{array}$ & $\begin{array}{c}0.24 \\
\pm 0.35\end{array}$ & $\begin{array}{c}0.57 \\
\pm 0.58\end{array}$ & $\begin{array}{c}0.06 \\
0.08 \pm\end{array}$ & $\begin{array}{c}0.08 \\
\pm 0.11\end{array}$ & $\begin{array}{c}0.06 \\
\pm 0.58\end{array}$ \\
\hline
\end{tabular}

Table (4A). Complete Blood Picture (CBC) Of Tilapia Zilli During The Period From April To August 2016.

\begin{tabular}{|c|c|c|c|c|c|c|c|}
\hline \multirow{2}{*}{$\begin{array}{c}\text { Fish } \\
\text { Group }\end{array}$} & \multirow{2}{*}{$\begin{array}{l}\text { Month } \\
\text { (2016) }\end{array}$} & \multirow[t]{2}{*}{ Fish Sex } & \multicolumn{5}{|c|}{ Complete Blood Picture } \\
\hline & & & HGB $10^{3} / \mu 1$ & RBCs $10^{6} / \mu 1$ & НCТ \% & $\mathrm{MCV} \mathrm{Fl}$ & $\mathrm{MCH} \mathrm{Pg}$ \\
\hline \multirow{10}{*}{$\begin{array}{c}\text { Breeding } \\
\text { Forms }\end{array}$} & \multirow[t]{2}{*}{ April } & Male & 13.10 & 1.30 & 31.50 & 153 & 64 \\
\hline & & Female & 11.00 & 1.70 & 23.35 & 144 & 66 \\
\hline & \multirow[t]{2}{*}{ May } & Male & 11.40 & 1.71 & 26.30 & 152 & 67 \\
\hline & & Female & 9.60 & 1.70 & 19.39 & 127 & 67 \\
\hline & \multirow[t]{2}{*}{ June } & Male & 10.20 & 1.81 & 25.10 & 138 & 59 \\
\hline & & Female & 10.60 & 1.80 & 25.17 & 140 & 58 \\
\hline & \multirow[t]{2}{*}{ July } & Male & 10.00 & 1.67 & 22.70 & 136 & 60 \\
\hline & & Female & 11.70 & 1.90 & 24.96 & 131 & 61 \\
\hline & \multirow[t]{2}{*}{ August } & Male & 11.50 & 1.83 & 24.50 & 134 & 63 \\
\hline & & Female & 12.40 & 1.70 & 26.89 & 125 & 58 \\
\hline \multicolumn{3}{|c|}{ Mean \pm SD } & $11.15 \pm 1.10$ & $1.71 \pm 0.16$ & $24.99 \pm 3.11$ & $138 \pm 9.55$ & $62.3 \pm 3.59$ \\
\hline \multirow{10}{*}{$\begin{array}{c}\text { Non- } \\
\text { Breeding } \\
\text { Forms }\end{array}$} & \multirow[t]{2}{*}{ April } & Male & 9.30 & 1.35 & 17.4 & 129 & 69 \\
\hline & & Female & 9.69 & 1.70 & 23.15 & 133 & 55 \\
\hline & \multirow[t]{2}{*}{ May } & Male & 12.50 & 1.87 & 26.60 & 102 & 67 \\
\hline & & Female & 13.10 & 1.90 & 24.40 & 132 & 67 \\
\hline & \multirow[t]{2}{*}{ June } & Male & 6.90 & 1.80 & 25.50 & 130 & 38 \\
\hline & & Female & 11.70 & 1.80 & 26.90 & 147 & 58 \\
\hline & \multirow[t]{2}{*}{ July } & Male & 12.90 & 2.11 & 30.50 & 133 & 61 \\
\hline & & Female & 10.80 & 1.70 & 26.50 & 134 & 58 \\
\hline & \multirow[t]{2}{*}{ August } & Male & 11.10 & 2.04 & 27.50 & 134 & 54 \\
\hline & & Female & 10.40 & 1.80 & 28.50 & 136 & 58 \\
\hline & \multicolumn{2}{|c|}{ Mean \pm SD } & $10.84 \pm 1.90$ & $1.81 \pm 0.21$ & $25.70 \pm 3.56$ & $\begin{array}{r}131.04 \\
\pm 11.21\end{array}$ & $58.50 \pm 8.91$ \\
\hline
\end{tabular}


Reproductive Behaviour, Hematological Profile and MonogeneanMicrofaunaof the Nest-

Table (4B). Complete Blood Picture (CBC) Of Tilapia Zilli During The Period From April To August 2016.

\begin{tabular}{|c|c|c|c|c|c|c|c|c|}
\hline \multirow{2}{*}{$\begin{array}{c}\text { Fish } \\
\text { Group }\end{array}$} & \multirow{2}{*}{$\begin{array}{l}\text { Month } \\
\text { (2016) }\end{array}$} & \multirow[t]{2}{*}{ Fish sex } & \multicolumn{6}{|c|}{ Complete Blood Picture } \\
\hline & & & $\begin{array}{l}\text { WBCs } \\
10^{3} / \mu 1\end{array}$ & $\begin{array}{l}\text { LYM } \\
10^{3} / \mu 1\end{array}$ & $\begin{array}{c}\text { PLT } \\
10^{3} / \mu 1\end{array}$ & $\begin{array}{c}\text { RDWc } \\
\%\end{array}$ & $\begin{array}{c}\text { MPV } \\
\text { fl }\end{array}$ & $\begin{array}{c}\text { PDWc } \\
\%\end{array}$ \\
\hline \multirow{10}{*}{$\begin{array}{c}\text { Breeding } \\
\text { Forms }\end{array}$} & \multirow[t]{2}{*}{ April } & Male & 115 & 62.90 & 93 & 11 & 8.00 & 38.00 \\
\hline & & Female & 97 & 45.20 & 173 & 12 & 8.00 & 11.70 \\
\hline & \multirow[t]{2}{*}{ May } & Male & 82 & 75.40 & 140 & 11 & 9.60 & 39.00 \\
\hline & & Female & 74 & 64.20 & 133 & 15 & 8.00 & 38.20 \\
\hline & \multirow[t]{2}{*}{ June } & Male & 99 & 72.40 & 150 & 12 & 8.10 & 38.00 \\
\hline & & Female & 86 & 72.20 & 141 & 12 & 9.20 & 38.20 \\
\hline & \multirow[t]{2}{*}{ July } & Male & 99 & 75.20 & 148 & 18 & 9.60 & 40.00 \\
\hline & & Female & 90 & 80.90 & 141 & 15 & 10.00 & 41.50 \\
\hline & \multirow[t]{2}{*}{ August } & Male & 92 & 72.60 & 148 & 13 & 9.80 & 41.00 \\
\hline & & Female & 85 & 85.40 & 140 & 16 & 8.90 & 39.60 \\
\hline \multicolumn{3}{|c|}{$\begin{array}{l}\text { Mean } \\
\pm \text { SD. }\end{array}$} & $\begin{array}{c}91.9 \\
\pm 11.38\end{array}$ & $\begin{array}{c}70.64 \\
\pm 11.18\end{array}$ & $\begin{array}{r}140.70 \\
\pm 19.92\end{array}$ & $\begin{array}{r}13.50 \\
\pm 2.37\end{array}$ & $\begin{array}{c}8.92 \\
\pm 0.83\end{array}$ & $\begin{array}{l}36.52 \\
\pm 8.81\end{array}$ \\
\hline \multirow{10}{*}{$\begin{array}{c}\text { Non- } \\
\text { breeding } \\
\text { Forms }\end{array}$} & \multirow[t]{2}{*}{ April } & Male & 120 & 40.40 & 122 & 12 & 8.80 & 39.00 \\
\hline & & Female & 99 & 69.50 & 81 & 21 & 8.50 & 39.00 \\
\hline & \multirow[t]{2}{*}{ May } & Male & 104 & 40.40 & 120 & 12 & 8.80 & 39.00 \\
\hline & & Female & 100 & 71.90 & 140 & 18 & 8.90 & 39.80 \\
\hline & \multirow{2}{*}{ June } & Male & 118 & 69.20 & 171 & 23 & 5.70 & 7.00 \\
\hline & & Female & 98 & 80.50 & 137 & 15 & 9.70 & 40.00 \\
\hline & \multirow[t]{2}{*}{ July } & Male & 115 & 68.30 & 73 & 20 & 7.90 & 37.00 \\
\hline & & Female & 95 & 83.20 & 137 & 16 & 8.50 & 38.50 \\
\hline & \multirow[t]{2}{*}{ August } & Male & 95 & 75.10 & 86 & 16 & 8.50 & 38.50 \\
\hline & & Female & 87 & 88 & 115 & 18 & 9.00 & 37.90 \\
\hline \multicolumn{3}{|c|}{$\begin{array}{c}\text { Mean } \\
\pm \text { SD }\end{array}$} & $\begin{array}{r}103.10 \\
\pm 11.02 \\
\end{array}$ & $\begin{array}{r}68.56 \\
\pm 16.25 \\
\end{array}$ & $\begin{array}{r}115.70 \\
\pm 31.95\end{array}$ & $\begin{array}{r}17.10 \\
\pm 3.63\end{array}$ & $\begin{array}{c}8.43 \\
\pm 1.06\end{array}$ & $\begin{array}{r}35.57 \\
\pm 10.08 \\
\end{array}$ \\
\hline
\end{tabular}

WBCs: White blood cells PLT: Platelets MPV: Mean platelet volume LYM: Lymphocytes

RDWc: Red cell distribution widthPDWc: Platelet distribution width

Table (5A). Levels Of Estrogen In The Blood Of The Breeding And Non-Breeding Females Of Tilapia Zilli.

\begin{tabular}{|c|c|c|c|}
\hline Fish Group & Month (2016) & Gender & $\begin{array}{c}\text { Estrogen } \\
(\mathrm{pg} / \mathrm{ml})\end{array}$ \\
\hline \multirow{5}{*}{$\begin{array}{l}\text { Breeding } \\
\text { Forms }\end{array}$} & April & \multirow{5}{*}{ Female } & 164.80 \\
\hline & May & & 395.70 \\
\hline & June & & 453.2 \\
\hline & July & & 782.60 \\
\hline & August & & 707.00 \\
\hline \multicolumn{3}{|c|}{ Mean \pm SD } & $500.66 \pm 249.07$ \\
\hline \multirow{5}{*}{$\begin{array}{c}\text { Non-breeding } \\
\text { Forms }\end{array}$} & April & \multirow[t]{5}{*}{ Female } & 620.00 \\
\hline & May & & 150.10 \\
\hline & June & & 301.70 \\
\hline & July & & 578.50 \\
\hline & August & & 133.80 \\
\hline \multicolumn{3}{|c|}{ Mean \pm SD } & $396.82 \pm 202.01$ \\
\hline
\end{tabular}

Table (5B). Levels Of Testosterone In The Blood Of The Breeding And Non-Breeding Males Of Tilapia Zilli.

\begin{tabular}{|c|c|c|c|}
\hline Fish Group & Month (2016) & Gender & $\begin{array}{l}\text { Testosterone } \\
(\mathrm{ng} / \mathrm{ml})\end{array}$ \\
\hline \multirow{5}{*}{$\begin{array}{l}\text { Breeding } \\
\text { Forms }\end{array}$} & April & \multirow[t]{5}{*}{ Male } & 9.15 \\
\hline & May & & 7.53 \\
\hline & June & & 3.24 \\
\hline & July & & 2.84 \\
\hline & August & & 1.35 \\
\hline \multicolumn{3}{|c|}{ Mean \pm SD } & $4.82 \pm 3.34$ \\
\hline \multirow{5}{*}{$\begin{array}{c}\text { Non-breeding } \\
\text { Forms }\end{array}$} & April & \multirow[t]{5}{*}{ Male } & 6.62 \\
\hline & May & & 0.70 \\
\hline & June & & 2.70 \\
\hline & July & & 0.89 \\
\hline & August & & 7.06 \\
\hline \multicolumn{3}{|c|}{ Mean \pm SD } & $3.59 \pm 3.07$ \\
\hline
\end{tabular}


Reproductive Behaviour, Hematological Profile and MonogeneanMicrofaunaof the Nest-

Table (6). Antioxidant Activity Parameters In Fish Blood Of The Breeding And Non-Breeding Forms Of Tilapia Zilli.

\begin{tabular}{|c|c|c|c|c|c|c|c|}
\hline \multirow[t]{2}{*}{ Fish Group } & \multirow[b]{2}{*}{$\begin{array}{l}\text { Month } \\
\text { (2016) }\end{array}$} & \multirow[b]{2}{*}{ Fish Sex } & \multicolumn{5}{|c|}{ Antioxidant Activity } \\
\hline & & & $\begin{array}{c}\mathrm{NO} \\
\mu \mathrm{mol} / 1\end{array}$ & $\begin{array}{c}\text { Catalase } \\
\mathrm{u} / \text { tissue }\end{array}$ & $\begin{array}{c}\mathrm{MDA} \\
\mathrm{nmol} / \mathrm{g} . \\
\text { tissue }\end{array}$ & $\begin{array}{c}\text { GST } \\
\text { u/g. tissue }\end{array}$ & $\begin{array}{l}\mathrm{GSH} \\
\mathrm{Mg} / \mathrm{g} . \\
\text { tissue }\end{array}$ \\
\hline \multirow{10}{*}{$\begin{array}{l}\text { Breeding } \\
\text { Forms }\end{array}$} & \multirow[t]{2}{*}{ April } & Male & 14.30 & 0.15 & 80.5 & 0.20 & 0.96 \\
\hline & & Female & 4.14 & 0.19 & 46.20 & 0.18 & 26.79 \\
\hline & \multirow[t]{2}{*}{ May } & Male & 7.32 & 0.77 & 37.8 & 0.15 & 7.52 \\
\hline & & Female & 15.90 & 0.84 & 53.18 & 0.55 & 7.85 \\
\hline & \multirow[t]{2}{*}{ June } & Male & 14.5 & 1.48 & 54.0 & 0.10 & 1.50 \\
\hline & & Female & 3.00 & 1.70 & 10.36 & 0.20 & 11.22 \\
\hline & \multirow[t]{2}{*}{ July } & Male & 7.00 & 1.27 & 5.7 & 0.60 & 1.20 \\
\hline & & Female & 8.50 & 1.36 & 13.10 & 0.30 & 4.12 \\
\hline & \multirow[t]{2}{*}{ August } & Male & 4.50 & 1.25 & 25.1 & 0.45 & 6.24 \\
\hline & & Female & 14.50 & 1.56 & 50.55 & 2.04 & 22.28 \\
\hline \multicolumn{3}{|c|}{ Mean \pm SD } & $\begin{array}{c}8.80 \\
\pm 4.96\end{array}$ & $\begin{array}{c}0.88 \\
\pm 0.58\end{array}$ & $\begin{array}{c}36.22 \\
\pm 23.83\end{array}$ & $\begin{array}{c}0.30 \\
\pm 0.58\end{array}$ & $\begin{array}{c}7.49 \\
\pm 8.91\end{array}$ \\
\hline \multirow{10}{*}{$\begin{array}{l}\text { Non-Breeding } \\
\text { forms }\end{array}$} & \multirow[t]{2}{*}{ April } & Male & 11.15 & 0.49 & 132.8 & 0.30 & 1.49 \\
\hline & & Female & 17.50 & 2.82 & 70.75 & 1.37 & 7.49 \\
\hline & \multirow[t]{2}{*}{ May } & Male & 3.00 & 1.77 & 48.10 & 0.20 & 2.45 \\
\hline & & Female & 5.5 & 1.73 & 69.20 & 0.11 & 3.06 \\
\hline & \multirow[t]{2}{*}{ June } & Male & 2.50 & 1.49 & 70.50 & 0.44 & 3.91 \\
\hline & & Female & 2.00 & 1.90 & 45.50 & 0.30 & 1.20 \\
\hline & \multirow[t]{2}{*}{ July } & Male & 3.00 & 2.04 & 124.80 & 3.35 & 9.37 \\
\hline & & Female & 5.00 & 1.94 & 39.17 & 0.39 & 9.58 \\
\hline & \multirow[t]{2}{*}{ August } & Male & 7.50 & 1.59 & 19.00 & 0.65 & 2.49 \\
\hline & & Female & 13.00 & 1.51 & 72.54 & 1.53 & 5.20 \\
\hline \multicolumn{3}{|c|}{ Mean \pm SD } & $\begin{array}{c}6.35 \\
\pm 5.24\end{array}$ & $\begin{array}{c}1.75 \\
\pm 0.58\end{array}$ & $\begin{array}{c}68.87 \\
\pm 35.87\end{array}$ & $\begin{array}{c}0.79 \\
\pm 1.00\end{array}$ & $\begin{array}{c}4.56 \\
\pm 3.15\end{array}$ \\
\hline
\end{tabular}

NO: Nitric oxide $\quad$ GST, GSH: Glutathione $\quad$ MDA: Malondialdehyde in plasma

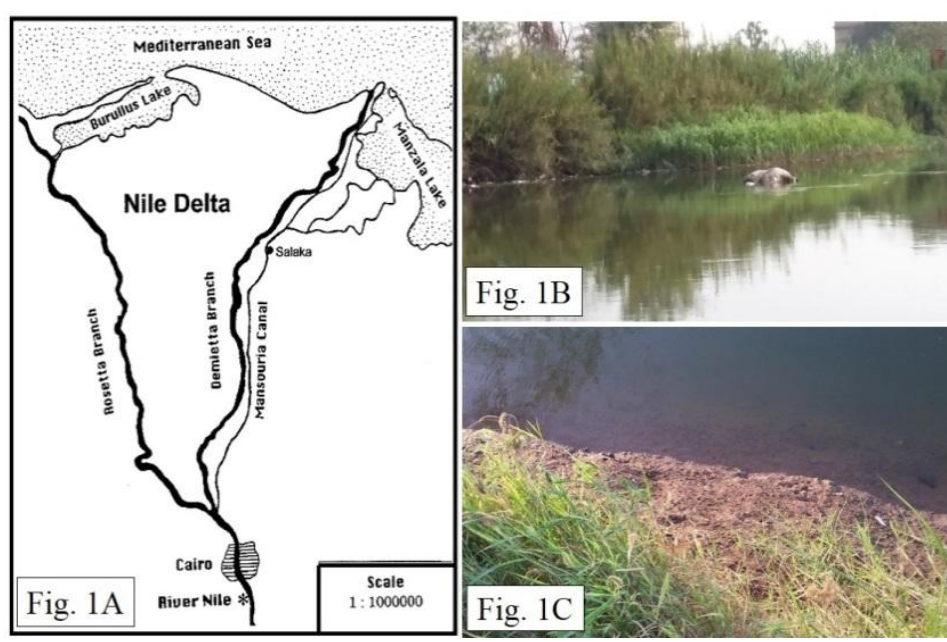



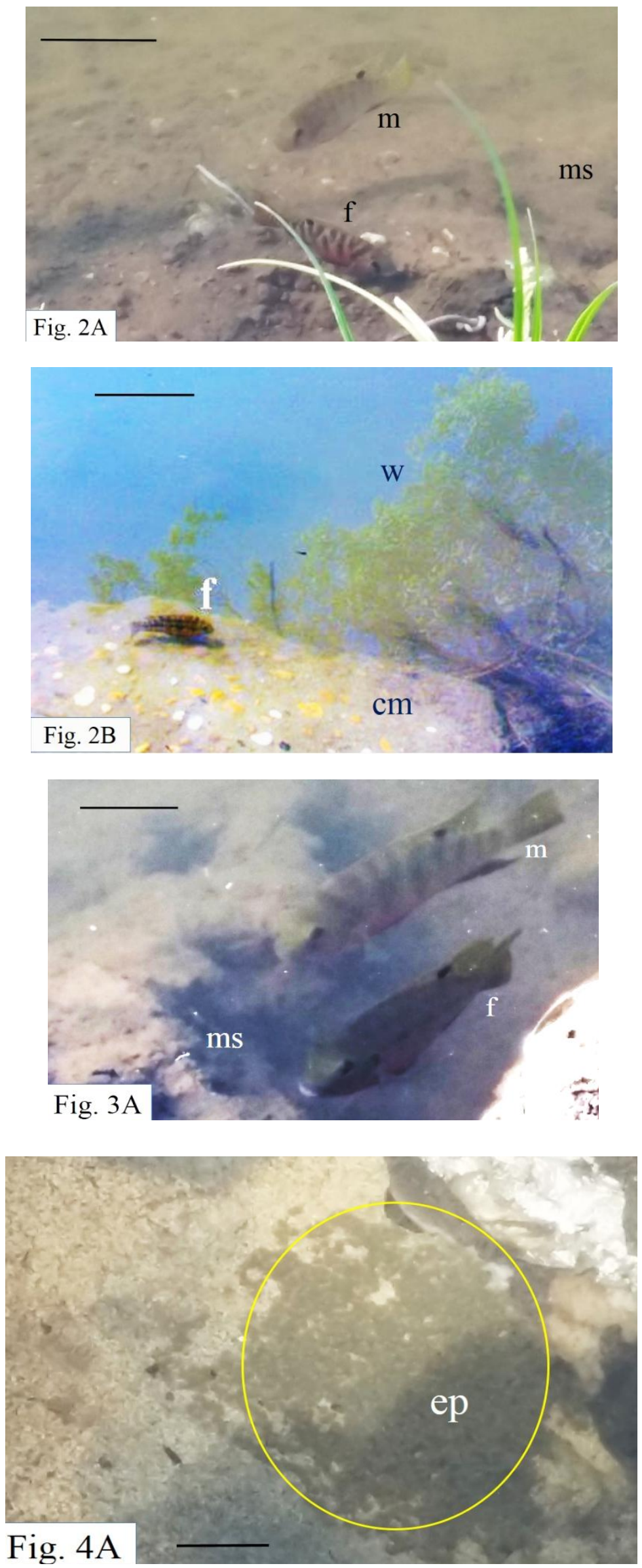

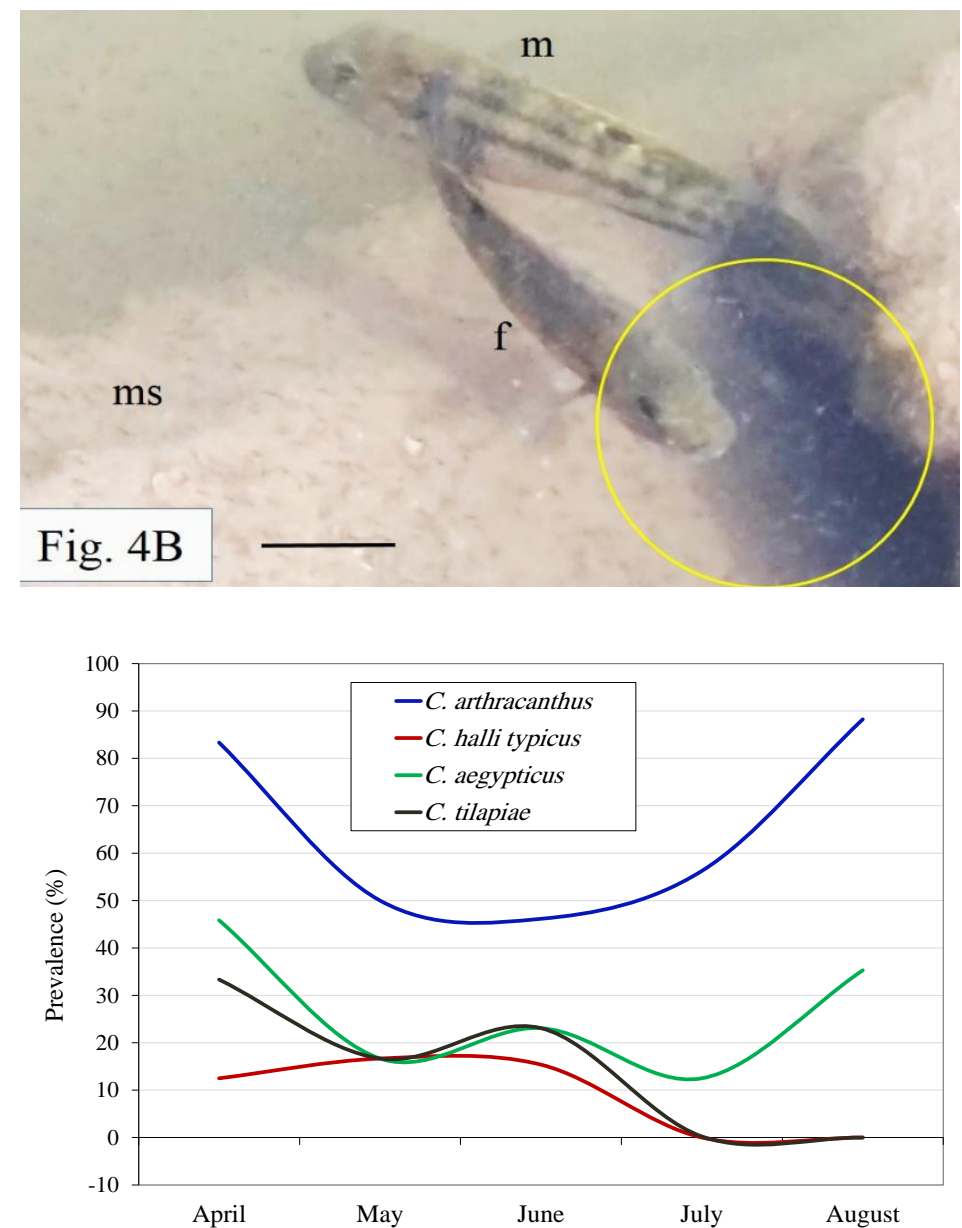

Fig. (5): Monthly Fluctuations Of The Prevalences Of The Gill Monogeneans On The Breeding Forms Of tilapia Zilli.

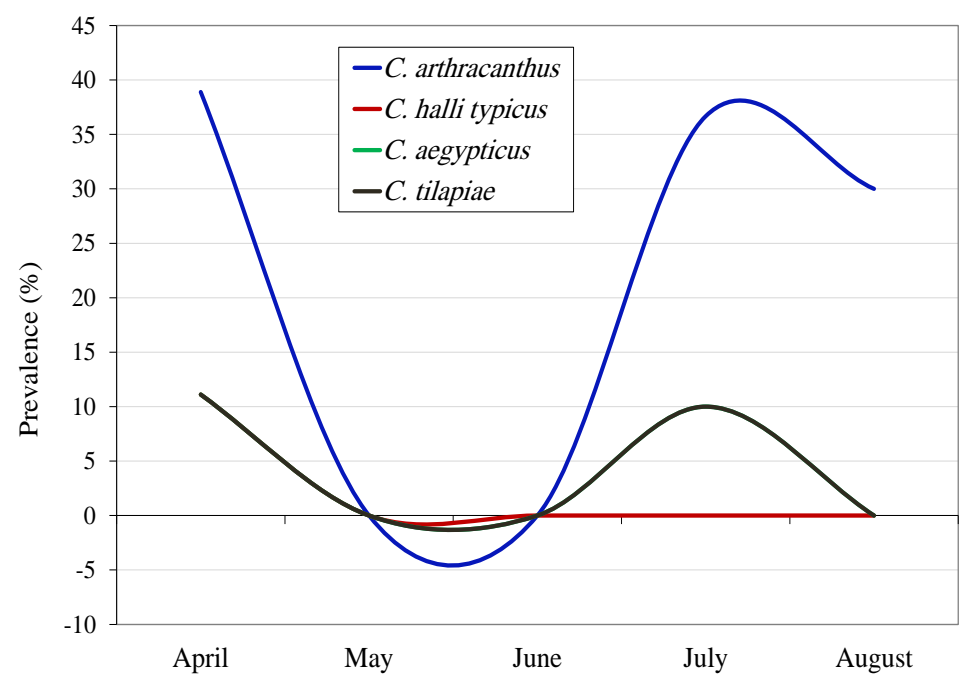

Fig. (6): Monthly Fluctuations Of The Prevalences Of The Gill Monogeneans On The Non-Breeding Forms Of Tilapia Zilli. 


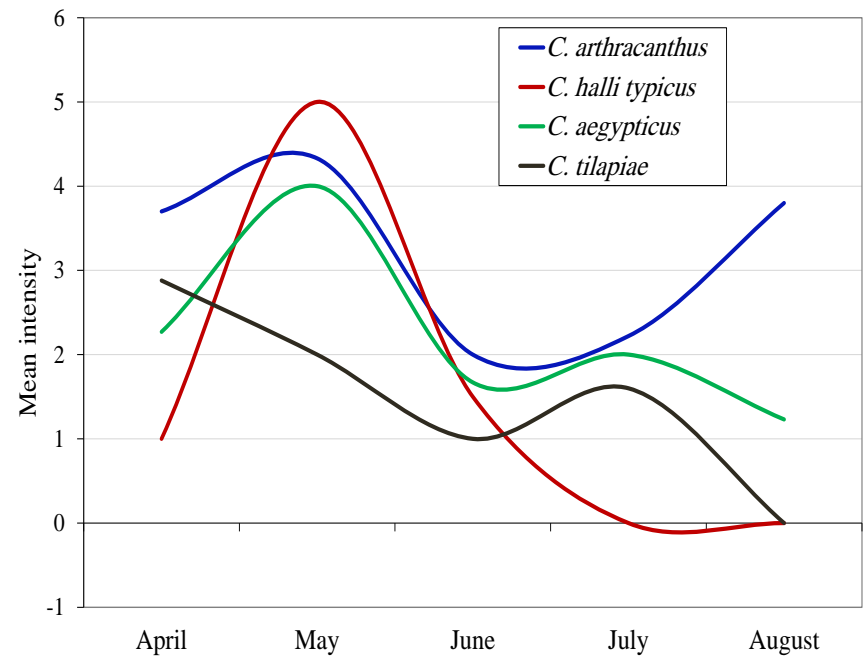

Fig. (7): Monthly Fluctuations Of The Mean Intensity Values Of The Monogeneanson The Breeding Forms Of Tilapia Zilli.

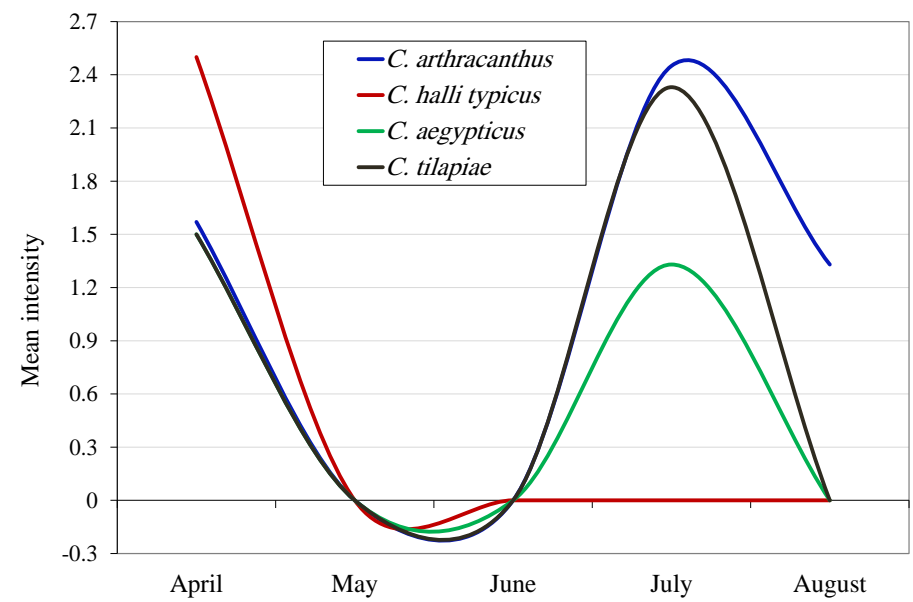

Fig. (8): Monthly Fluctuations Of The Mean Intensity Values Of The Gill Monogeneanson The Non-Breeding Forms Of tilapia Zilli.

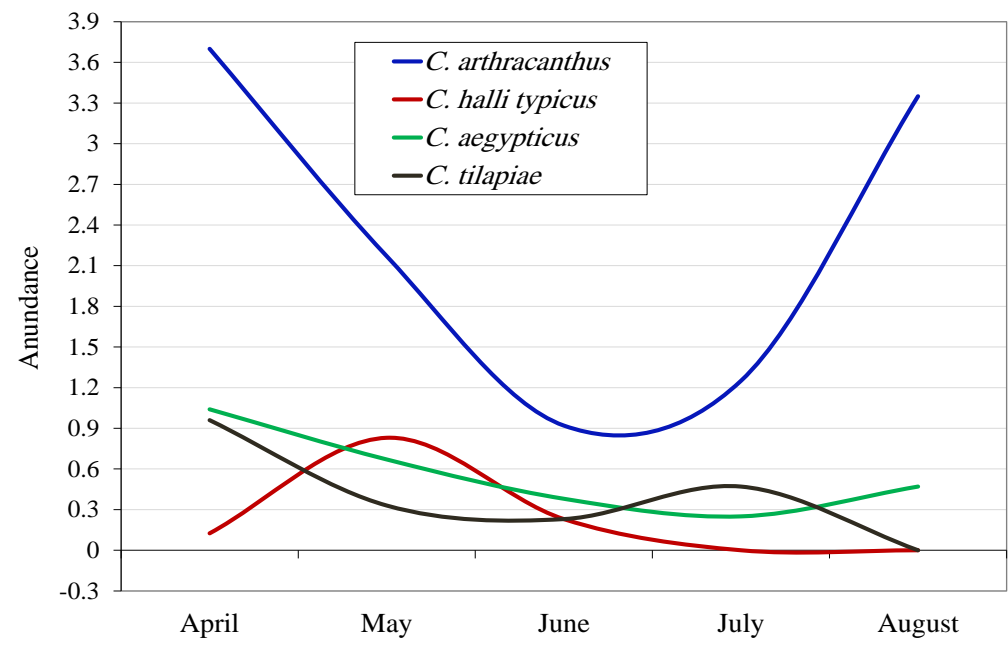

Fig. (9): Monthly Fluctuations Of The Abundances Of The Gill Monogeneanson The Breeding Forms Of Tilapia Zilli. 


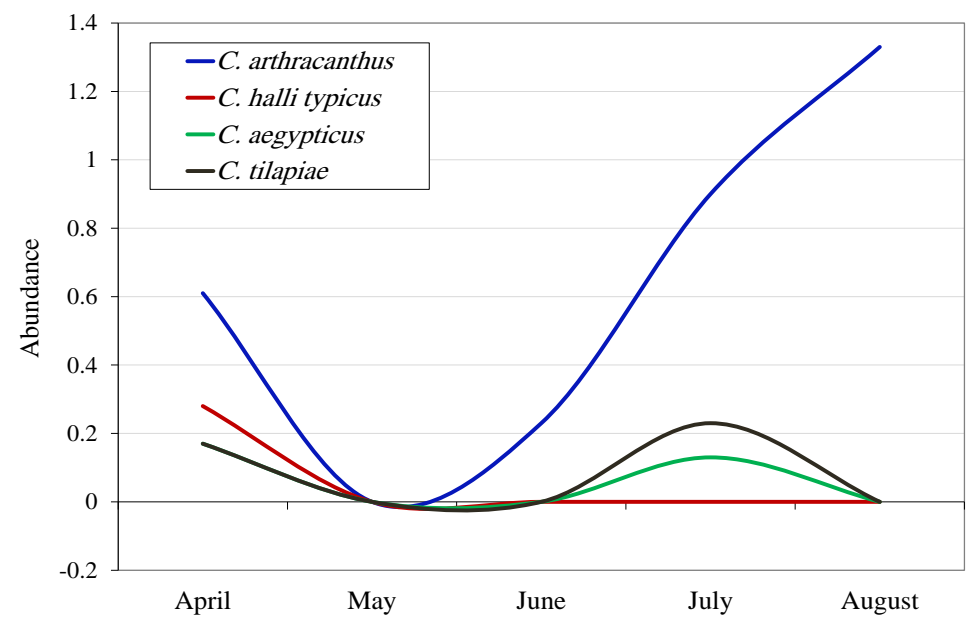

Fig. (10): Monthly Fluctuations Of The Abundances Of The Gill Monogeneanson The Non-Breeding Forms Of Tilapia Zilli.

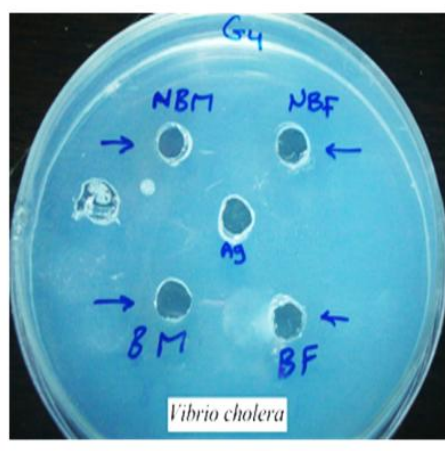

Fig. $11 \mathrm{~A}$

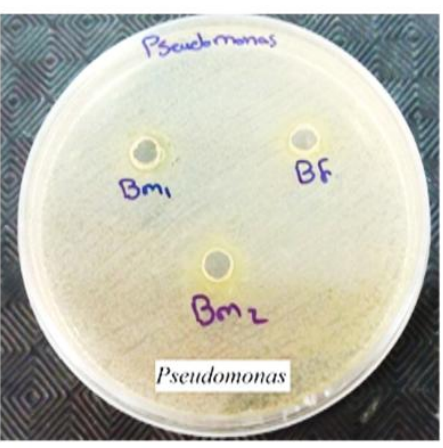

Fig. 11B

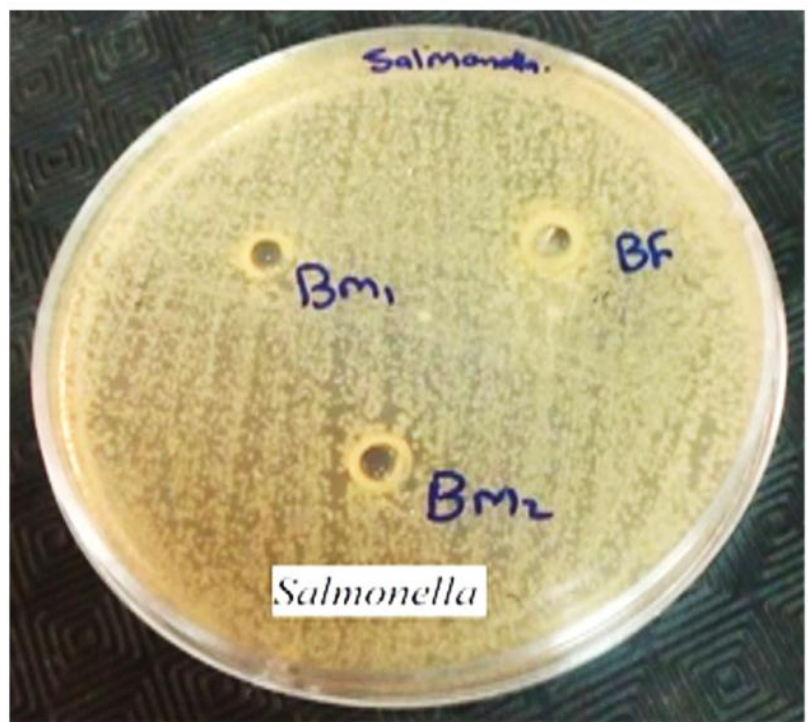

Fig. 11C 


\section{Explanation Of Figures}

Fig. 1.Description of the investigation area. A) Map showing the location of Salaka Village atMansouria Canal in the vicinityof Mansoura City, Nile Delta, Egypt. B) Photograph showing one of the sources of contamination (dead animals) of the waterbodyatMansouria Canal. C) Photograph showing the marked drop in the level of water inMansouria Canal during September, 2016. D) Google Earth Satellite image showing a sector of Mansouria Canal nearby Mansoura City.

Fig. 2. Photomicrograph showing the nesting forms of Tilapia zilli. A) Breeding male andfemale begin to prepare the nest on a muddy substrate. Note the markedcolouration of the body of mating partners. Scale bar $=80 \mathrm{~mm}$. B) Breeding female waiting a mating partner on a concrete mass. Scale bar $=90 \mathrm{~mm}$. cm, concrete mass; f, female; $\mathrm{m}$, male; $\mathrm{w}$, aquatic weeds.

Fig. 3. Photomicrograph showing thebreeding forms of Tilapia zilli. A) Large-sized mates occupying a vertical groove close to the shoreline of Mansouria Canal. Scale bar $=40 \mathrm{~mm}$. B) Breeding male attaining attractive colouration during the spawning period. Scale bar $=45 \mathrm{~mm}$. Note the distinctive, dark vertical strands across the body of the breeding male,red throat and abdomen, and shiny yellowish colouration of the lateral sides of the body. $\mathrm{f}$, female; $\mathrm{m}$, male; ms, muddy substrate.

Fig. 4. Photomicrograph showing egg patch and parental careinTilapia zilli. A) Hundreds of deposited eggs on contaminated, muddy substrate. Scale bar $=30 \mathrm{~mm}$. B) Breeding male and female providing intensive care to the newly hatched larvae (yellow circle). Note that the male secures the margins of the nest, whereas the female devotes her effort to safeguard and guide the offspring. Scale bar $=40 \mathrm{~mm}$. ep, egg patch; $\mathrm{f}$, female; $\mathrm{m}$, male; ms, muddy substrate.

\section{References}

[1] A.Svetina,Ż.Matašin, A.Tofant, M. Vuèemilo, and N.Fuan, Haematology and some blood chemical parameters of young carp till the age of three years,ActaVeterinariaHungarica, 50, 2002, 459-467.

[2] M.Pavlidis, W. C.Futter, P. Katharios, and P.Divanach, Blood cell profile of six Mediterranean mariculture fish species,Journal of Applied Ichthyology, 23, 2007, 70-73.

[3] U.Gabriel, O. A. Akinrotimi, and F. Eseimokumo, Haematological responses of wild Nile tilapia Oreochromisniloticus after acclimation to captivity,Journal of Biological Sciences, 4, 2011, 225-230.

[4] G. P. Moberg, and J. A.Mench, The Biology of Animal Stress: Basic Principles and Implications for Animal Welfare (Cabi). Firs Edition, 2000,pp. 384

[5] O. A.Akinrotimi, O. M. G.Abu, E. J.Ansa, O. M. Edun, andO. S. George, Haematological responses of Tilapia guineensis to acute stress. International Journal of Natural and Applied Sciences, 5(47), 2009, 338 -343.

[6] E. Omoregie, and O. Oyebanji, Oxytetracycline induced blood disorder in Nile tilapia, Oreocliromisniloticus. Journal of the World Aquaculture Society, 33(3), 2002, 377-382.

[7] U.Gabriel, G. N. O. Ezeri, and O. O. Opabunmi, Influence of sex, source, health status and acclimation on the haematology of Clariasgariepinus (Burchell, 1822). African Journal of Biotechnology, 3, 2004, 463-467.

[8] M. N. Fernades and A. F. Mazon, Environmental Pollution and fish gill morphology fish Adaptations. In: Val A.L. and Kapour B C. (eds). Science Publications. Enfield, USA, 2003, 203-231.

[9] G.Iwama and T.Nakanishi, The Fish Immune System: Organism, Pathogen, and Environment, Volume 15 1st Edition. Academic Press, 2003,pp. 380.

[10] V.Luskova, Factors Affecting Haematological Indices in Free-living Fish Populations. ActaVeterinaria Brno, 67, 1998, 249-255.

[11] T. W. Campbell, (2004). Hematology of lower vertebrates. In: Proc. of the 55th Annual Meeting of the American College of Veterinary Pathologists (ACVPC) and $39^{\text {th }}$ Annual Meeting of the American Society of Clinical Pathology, USA.

E.Bielek andB.Strauss, Ultrastructure of the granulocyte of the South American lungfish, Lepidosirenparadoxa: Morphogenesis and comparison to other leucocytes. Journal of Morphology, 1993, 218: 29-41.

T. C.Hrubec, S. A. Smith, and J. L. Robertson, Age-related in hematology and plasma chemistry values of hybrid striped bass (Moronechrysops $\times$ Moronesaxatilis). Veterinary Clinical Pathology, 30, 2001, 8-15.

[12] G. N. O.Ezeri, U. U. Gabriel, and O. O. Opabunmi, Haematological response of cultured and wild Clariasgariepinus to acclimation. Environment and Ecology, 22(3), 2004, 1-5.

[13] G. R. Vázquez, and G. A. Guerrero, Characterization of blood cells and hematological parameters in Cichlasomadimerus (Teleostei, Perciformes). Tissue Cell, 39, 2007, 151-160.

[14] S.Braude, Z. Tang-Martinez, and G. T. Taylor, Stress, testosterone, and the immunoredistribution hypothesis.Behavioral Ecology, $10,1999,345-350$

[15] I. Folstad, and A. J. Karter, (1992). Parasites, bright males, and the immunocompetence handicap.American Naturalist, 139, 1992, $603-622$.

[16] C. Wedekind, and F. Folstad, Adaptive or nonadaptive immunosuppression by sex hormones?American Naturalist, 143, 1994, 936938.

[17] N.Hillgarth, M. Ramenofsky, and J. Wingfield, Testosterone and sexual selection.Behavioral Ecology, 8, 1997, 108-109.

[18] K.Rohlenová, S.Morand, P.Hyršl, S.Tolarová, M. Flajšhans, and A. Šimková, Are fish immune systems really affected by parasites? animmunoecological study of common carp (Cyprinuscarpio). Parasites and Vectors, 4, $2011,120$.

[19] E.Dadebo, N.kebtineh, S.Sorsa, and K. Balkew, Food and Feeding habits of the red-belly Tilapia (Tilapia zilli, Gervais, 1848) (Pisces: Cichlidae) in lake Ziway, Ethiopia. Agriculture, Forestry and Fisheries, 3(1), 2014, 17-23.

[20] G. Fryer, and T. D. Iles, The cichlid fishes of the great lakes of Africa.T.F.H.Publications, Neptune City, New Jersey. 1972.

[21] J. C. Philippart, and J. C. Ruwet, Ecology and distribution of tilapias. Pages 15-59 in R. S. V. Pullin and R. H. Lowe-McConnell, editors. The biology and culture of tilapias.International Center for Living Aquatic Resources Management, Manila. 1982.

[22] J. L. Marcon, and D. W. Filho, Antioxidant processes of wild tambaqui, Colossomamacripomum (Osteichthyes: Serrasalmidae) from the Amazon. Comparative Biochemistry and Physiology, 123(C), 1999, 257-263.

[23] P. Matthiessen, Endocrine disruption in marine fish. Pure and Applied Chemistry, 75, 2003, $2249-2261$. 
[24] N. Candan, and N. Tuzmen, Very rapid quantification of malondialdehyde (MDA) in rat brain exposed to lead, aluminum and phenolic antioxidants by high-performance liquid chromatography-fluorescence detection. Neurotoxicology, 29, $2008,708-713$.

[25] C.Mirea, V.Cristea, R. I.Grecu, L. Dediu, and V. Ion, Hematological and Biochemical Characterization of Nile tilapia (Oreochromisniloticus, Linnaeus, 1758) Reared Intensively in a Recirculating Aquaculture System in Relation to Water Temperature. Animal Science and Biotechnologies, 46 (2), 2013, 234-237.

[26] A. A.Ezzat, M. B. Shabana, and A. M. Farghaly, Studies on the blood characteristic of Tilapia zilli (Gervais). Journal of Fish Biology, 6, 1973, 1-12.

[27] J. H. J. Van Vuren, and J. Hattingh, A seasonal study of the haematology of wild freshwater fish. Journal of Fish Biology, 13, 1978, 305-313.

[28] F.Fazio, S.Marafioti, A.Torre, M.Sanfilippo, M.Panzera, and C. Faggio, Haematological and serum protein profiles of Mugilcephalus: effect of two different habitats. Ichthyological Research, 60, 2013, 36-42.

[29] E.Cataldi, P.Di Marco, A. Mandich, and S. Cataudella, Serum parameters of Adriatic Sturgeon Acipensernaccarii (Pisces: Acipenseriformes): Effects of temperature and stress. Comparative Biochemistry and Physiology, 120, 1998, $273-278$.

[30] M. C. R. Symons, and J. M. C. Gutteridge, Superoxide, peroxides, and iron in biological systems In: Free Radicals and Iron: Chemistry, Biology, and Medicine, M.C.R. Symons and J.M.C. Gutteridge (Eds.), University Press, Oxford,1998, $113-137$.

[31] G.Mourente, D. R.Tocher, E.Díaz, A. Grau, and E. Pastor, Relationships between antioxidant enzyme activities and lipid peroxidation products during early development in Dentexdentex eggs and larvae. Aquaculture, 179, 1999, $309-324$.

[32] J. M.Belanger, J. H.Son, K. D.Laugero, G. P.Moberg, S. I.Dorochov, S. E. Lankford, and J. J. Cech, Effects of short-term management stress and ACTH injections on plasma cortisol levels in cultured white sturgeon, Acipensertransmontanus. Aquaculture, 203, 2001, 165-176.

[33] A. G. Heath, (1995). Water Pollution and Fish Physiology.CRC Press, 1995, pp. 384.

[34] D. H.Evans, J. B. Claiborneand S.Currie,The Physiology of Fishes, Fourth Edition (CRC Marine Biology Series), 4th Edition. CRC Press, 2013, pp. 491.

[35] S. M. Kawthalkar, Essentials of Haematology. Jaypee Brothers Medical Publishers, 2013, pp. 550.

[36] D. J. Weiss, andK. J. Wardrop, Schalm's Veterinary Hematology, 6 ${ }^{\text {th }}$ Edition. Wiley-Blackwell, 2010 , pp. 1232.

[37] H.Stosik, W.Deptula, and M. Travnicek, Studies on the number and ingesting ability of thrombocytes in sick carps (Cyprinuscarpio). Veterinary Medicine, 46, 2001, 12-16.

[38] C. N. Morrell, A. A. NAggrey, L. M. Chapman, and K. L. Modjeski, Emerging roles for platelets as immune and inflammatory cells. Blood, 123(18), 2014, 2759-2767.

[39] B. K. Manne, S. C. Xiang, and M. T. Rondina, Platelet secretion in inflammatory and infectious diseases. Platelets, 28(2), 2017, $155-164$.

[40] L.Passantino, A.Cianciotta, R.Patruno,M. R.Ribaud, E.Jirillo, G. F. Passantino, Do fish thrombocytes play an immunological role? Their cytoenzimatic profiles and function during an accidental piscine candidiasis in aquarium. Immunopharmacology and. Immunotoxicology, 27, 2005, 345-356.

[41] G. L. Prasad, and S. Charles, Haematology and leucocyte enzyme cytochemistry of a threatened yellow catfish Horabagrusbrachysoma (Gunther 1864). Fish Physiology and Biochemistry, 36(3), 2010, 435-43.

[42] G. Prasad, and G. L. Priyanka, Effect of fruit rind extract of Garciniagummi-gutta on haematology and plasma biochemistry of catfish Pangasianodonhypophthalmus. Asian Journal of Biochemistry, 6, 2011, 240-251.

[43] J. D.Biller-Takahashi, L. S. Takahashi, and C. M. Marzocchi, Hemolytic activity of alternative complement pathway as an indicator of innate immunity in pacu (Piaractusmesopotamicus). RevistaBrasileira de Zootecnia, 41, 2012, $237-241$.

[44] F.Garcia, S. H. C. Schalch, and E. M. Onaka, Hematologia de tilápia-do-niloalimentada com suplemento à base de algasfrente a desafios de estresseagudo e crônico. ArquivoBrasileiro de MedicinaVeterinária e Zootecnia, 64, 2012, 198-204.

[45] C. L. Milligan and C. M. Wood, Disturbances in haematology, fluid volume, distribution and circulatory function associated with low environmental $\mathrm{pH}$ in the rainbow trout Salmogairdneri. Journal of Experimental Biology, 99, 1982, 397-415. 